\title{
Historein
}

Vol 15, No 2 (2015)

Historein 15/2 (2015)

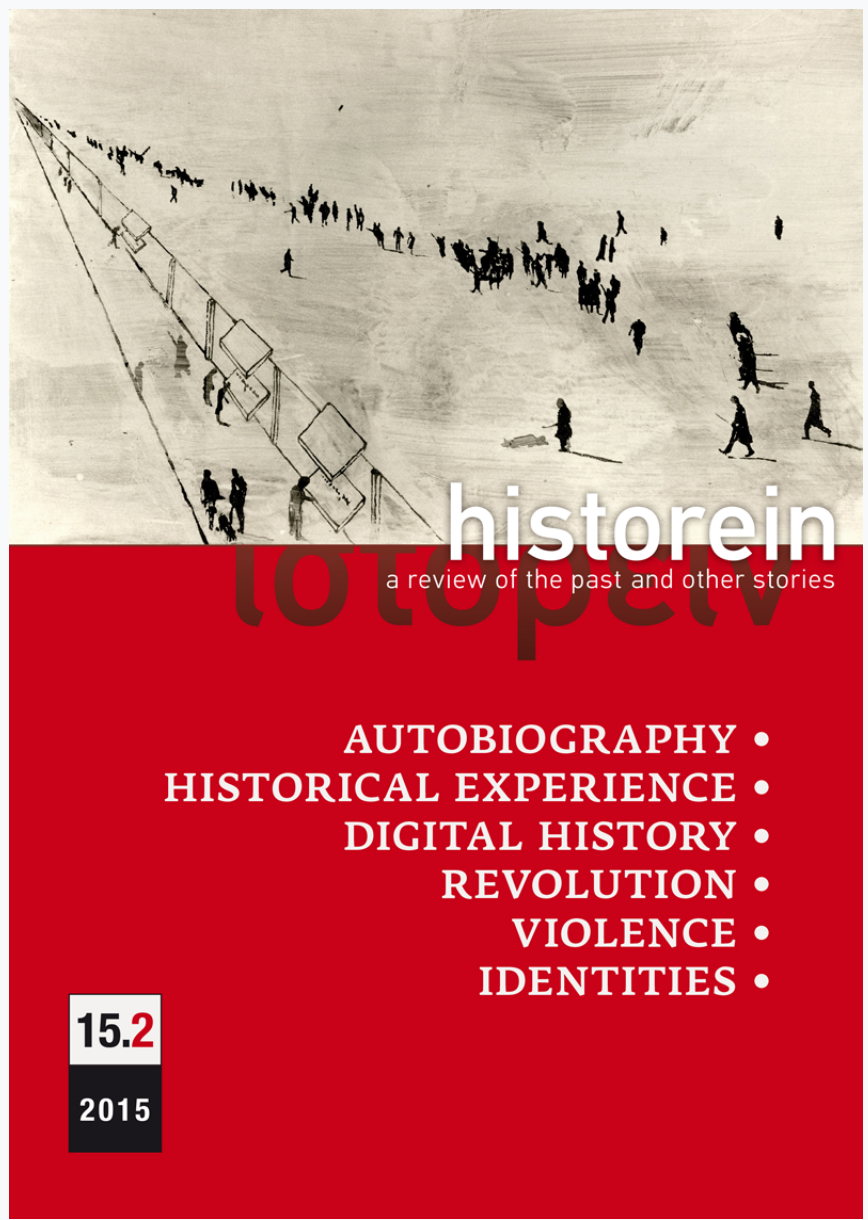

Vita magistra historiae? Life experience and meanings of the past

Rolf Petri

doi: $\underline{10.12681 / \text { historein.325 }}$

Copyright @ 2015, Rolf Petri

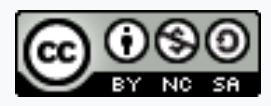

This work is licensed under a Creative Commons Attribution-NonCommercialShareAlike 4.0.

To cite this article:

Petri, R. (2016). Vita magistra historiae? Life experience and meanings of the past. Historein, 15(2), 6-20. https://doi.org/10.12681/historein.325 


\section{Vita magistra}

historiae?

\section{Life experience and meanings of the past}

\section{Rolf Petri}

Ca' Foscari University of Venice
How does the historian's personal experience of history interact with his or her professional choices? This is the question I want to reflect on by considering my own case. Since it is not a particularly remarkable one, it would be hardly significant enough to be narrated as such. 'As part of an experimental arrangement, it may nevertheless help in assessing the methodical reach of a new autobiographical genre to which eminent personalities of our profession have contributed in creating in recent years. ${ }^{2}$ Some of the authors apparently hope that their writing may help us to forge "new paradigms that will reinvigorate the humanities and address its crisis in subjectivity". ${ }^{3}$ My own case will show that life experience exerts an influence on the historian's choices that autobiographical narration can to a certain extent unveil. I will, however, argue that such narration has no particular theoretical and methodological credentials to account for a new subjectivity paradigm in historiography.

Mine is the memory of a German historian who was politicised in the 1970s, academically trained in the following two decades, and who perceived the turn of 1989 as a watershed for his professional life. Born in the late 1950s and as a boy who grew up in the 1960s, on the threshold of the 1970s I was dreaming of the other-places typical of a particular western youth culture of the time. Listening to rock, blues and jazz music on the radio during the years that followed the Monterey and Woodstock festivals allowed me to indulge in fantasy and evade the stuffy confines of a little rural village in North Rhine-Westphalia. It was the time when people like my parents, who were born in the late 1920s and grew up during the Nazi period, after consolidating their humble personal Wirtschaftswunder, began to elaborate on their past experience. Al- 
though they still appreciated some "valid aspects" of their juvenile experience, they never missed an election day as they now were convinced that western democracy was the best of all possible political systems. What a comfortable coincidence it was to be always in tune with mainstream ideas! I developed a certain scepticism regarding ideas on which everyone seems to agree even without actually thinking them through. I found my scepticism echoed in the lyrics of "What about me" by Quicksilver Messenger Service: "Your newspapers, they just put you on. They never tell you the whole story. They just put your young ideas down. I was wonderin' could this be the end of your pride and glory?" Upon hearing words like these, I discovered that one didn't need to grow up in a remote German village to share similar attitudes towards life. In my ears, the words "I feel like a stranger in the land where I was born"4 gave the song the solemnity of a national anthem. For I knew, as a matter of aesthetic judgment, that only a stranger's land could be my land. I felt a need for estrangement to better define what I thought or wanted to be.

Attitude towards life, or Lebensgefühl, was explained by Kant:

Here the representation is related entirely to the subject, indeed to its feeling of life, under the name of the feeling of pleasure or displeasure, which grounds an entirely special faculty for discriminating and judging that contributes nothing to cognition but only holds the given representation in the subject up to the entire faculty of representation, of which the mind becomes conscious in the feeling of its state. ${ }^{5}$

As it often happens to me when reading Kant, I find the wording meaningful but share little of the words' meaning. My life experience confirms to me that feelings of pleasure and displeasure, if at all distinguishable, more often stand in a dialectical relationship rather than as opposites. My scholarly experience teaches me that there is no cognition without aesthetical judgment, as feelings and "consciousness" in the complexity of the brain's interaction with its surroundings cannot be drawn apart. My theoretical reflection tells me that when something "is related entirely to the subject", it is most likely a philosophical fantasy. I rather feel that the subject as such, that is, as a concept, deserves to be subjected to critical reflection. It is this feeling that presided over my writing of the following text.

\section{Juvenile uneasiness with past and present}

Different psychological and anthropological commonplaces could be exerted to explain some traits of character to which I would assign a causality for my choices, and which - perhaps erroneously - appear to me as constants of my self-definition. Was it the echo of the Lutheran and pietistic education received from my family and the social context of the village that instilled in my mind a rather uncompromising sense of justice and a certain idea of righteousness? Sayn-Wittgenstein, the county where I grew up, was an area of Huguenot immigration in the seventeenth century and of chiliastic movements at the turn of the eighteenth century. ${ }^{6}$ Both developments vaguely interfered with my family history. As far as I was concerned, attempts at religious education ended in disaster, as I was perhaps "too intransigently Protestant" to accept the unfair one-sidedness of the 
sacred, which requires devotion without any disputation or scorn. Nevertheless my politicisation was strongly oriented by a passionate sense of justice, and of course I was not the only one. There were several levels of injustice to which we reacted, from the very microlevel of protest against what appeared to us pupils as the arbitrary behaviour of teachers, to macrolevels that had to do with world politics such as the Vietnam war, the military coup in Greece, the death of Che Guevara, the Soviet intervention in Prague and the 1968 student revolt. In 1971 for the first time, at the age of 14, I actively engaged in a petition campaign in protest against the imprisonment and incrimination of the American militant Angela Davis. ${ }^{7}$ Another key moment occurred in January 1972, when after preliminary measures taken by SPD-governed $L$ änder, the social democrat and liberal federal government under Willy Brandt passed a decree which became known as the Radikalenerlass.

The measure resulted in a purge of the public service of so-called extremists, almost exclusively supporters of left-wing and Marxist organisations. It is estimated that from 1971 to 1988, over one million candidates for civil service positions were "checked" by the secret service, ${ }^{8}$ and over 10,000 administrative or legal measures were taken that prevented citizens from starting or pursuing their career in the civil service; most of these cases occurred in the 1970s in SPD-governed Länder.? Faced with international protests, the German authorities denied that it was an occupational ban. This was correct from a formal point of view; however, impeding the appointment of a teacher to public schools and putting pressure on the few private schools to act in the same way was a de facto Berufsverbot. A leading SPD bureaucrat in the field of security and the secret services, Peter Frisch, who wrote a set of guidelines in favour of the Extremisten-Beschluss, added an odious paternalistic note regarding punishment and forgiveness that was similar to the tone of the Holy Inquisition: "The deceived idealist or the politically ingenuous citizen will, therefore, possibly not be rejected. However it should be ascertained that the candidate, after receiving appropriate elucidations, will clearly profess his commitment to the liberal and democratic fundamental order."10 Discourses such as this indicated to me the way to militancy within the ranks of the communist organisations that were the principle target of the discriminatory procedures.

After the damage to the German image abroad became evident, Brandt himself began to speak of a mistake. In the 1980s the SPD tried to erase its fingerprints as the original initiator of the measure by urging the now Christian democrat-led government to abandon it. After 1985 the automatic checking of all candidates by the secret service was gradually suspended, although occasional attempts were made to proceed with the same measures. Nevertheless, in 1995 the European Court of Human Rights, in Vogt versus Germany, ruled there had been a violation of the European Convention on Human Rights. A relatively recent text in defence of streitbare Demokratie (or militant democracy) states that "contrary to other western democracies, legal prosecution concerns not only the violation of criminal law, and in particular the use of violence for the attainment of extremist purposes, but apparently legal, peaceful activities in favour of the implementation of extremist ideologies can be sanctioned through the legal instruments of militant democracy"."1

What makes the argument of wehrhafte Demokratie so interesting in the present context is that during the third quarter of the twentieth century, the Berufsverbote linked the West German present back to all major aspects of post- 1900 German history. The fundamental references made by both the supporters and adversaries of the Radikalenerlass were to history. As an excellent study 
recently has pointed out, the massive reintegration of ex-Nazi elites into the West German civil service and university system, a process encouraged after 1949 by the USA in the context of the Cold War, was to the detriment not only of communists but also of other formerly exiled anti-Nazi personalities who in 1945 had been recruited by the Allied forces to build up democratic structures, only to become increasingly marginalised after 1949. ${ }^{2}$ This was the background which on the occasion of the banning of the Communist Party of Germany (KPD) in 1956 allowed the Federal Constitutional Court to reinterpret the antifascist protective measures contemplated by the German constitution in "anti-totalitarian" terms, which, according to several jurists, can hardly be deduced either by a strictly juridical reading of the text of the constitution itself or by the historical examination of parliamentary assembly debates while drafting the constitution. ${ }^{13}$ "The misleading reinterpretation of the basic law in the 1950s was due to law professors who had already been appointed during the Third Reich."14 The 1970s Berufsverbote made it even more clear that, in contrast to communist postmen and Marxist school teachers, "around half of the leading administrative and judicial personnel had been above all reproach when they were appointed, notwithstanding their former militancy in the NSDAP or related organisations"..$^{15}$ The reader may imagine the moral indignation of a young man seeing the Berufsverbot being used against Silvia Gingold, a teacher and daughter of persecuted and internationally renowned resistance militants, or a philosophy professor like Hans Heinz Holz, a former victim of Gestapo Schutzhaft (literally, "protective custody"), whose appointment was opposed by the political scientist Iring Fetscher, a second-generation exponent of the Frankfurt school and former NSDAP party member (number 7729137). Among the people who, to my disgust, defended "militant democracy" and the Berufsverbote as a historical achievement after the Weimar Republic's destruction "by right- and left-wing extremists" (the German schoolbook version until today), there were liberal intellectuals such as the most influential German sociologist of the time, Helmut Schelsky, who in the 1930s publicly professed particularly brutal Nazi ideas. ${ }^{16}$

However, I did not only feel indignation vis-à-vis the injustice that was inflicted on persons exercising their constitutional rights, in contrast to the smooth integration of recycled Nazi elites into the democratic structures of the Federal Republic. Thanks to my Marxist readings I also began to interpret the Berufsverbote as an expression of structural continuities rather than political paradoxes. Like most of my contemporaries, I was disconcerted about Germany's Nazi past, but felt that depicting it as an alien intrusion from the dark planet of "absolute evil" was an accommodating self-deception. Instead, I was convinced that the exceptionality of the Nazi system regarded mainly contingent political aspects, whereas the basic social, economic, cultural and ideological features of the period were deeply rooted in society. That I came to a similar conclusion was also due to my reading of early twentieth-century novels and romances. These readings allowed me another and, as I felt, deeper insight into German history and its continuities. They made me better understand of which history Nazism had been a product, of which history the Weimar Republic had been a product and what all this had to do with the First World War. After reading Arnold Zweig's romances, I meant to understand why warmongering and starting a war should be seen as the mother of all political crimes, and the original sin of German - and not just German - history.

In Education before Verdun Zweig ironically comments on the growing social democratic patriotism in the years running up to the First World War, writing that, as soon as "the white-collars released some sounds in black-white-red tonality, the proletarian heart lost all of its quiet. None other than 
August Bebel, bursting of patriotism from every pore and without considering the cost, took up his rifle to march against Russia." ${ }^{17}$ On 4 August 1914, one year after Bebel had passed away, social democratic MPs declared in the Reichstag their support for a war which they represented as a pre-emptive defence against an imminent Russian invasion. They solemnly vowed "to protect the culture and independence of our country" against the "sanguinary Russian despotism" of a tsar who had murdered thousands of Russian workers. ${ }^{18}$

After reading similar pages about the origins of the war both in novels and history books, I saw the apparent paradoxes of my present in a much more comprehensible light. I decided that, henceforth, the most important dividing line politically between "me" and "them" would be marked by whatsoever justification of whatsoever military aggression. By aggression, I refer to the same "supreme international crime" that Robert H. Jackson, US chief prosecutor at the Nuremberg Trials, imputed to the surviving Nazi cadres, and which he characterised unambiguously as an "invasion of [the aggressor's] armed forces, with or without a declaration of war, of the territory of another state". ${ }^{19}$ The pre-emptive war argument, the responsibility-to-protect argument, and the assertion of a relative value of (the other's) territorial sovereignty in an interdependent world, ${ }^{20}$ were typical excuses for that horrible crime already in 1939 and 1914. Ever since the 1970s, my early readings on the First World War shaped my view on the presents which I witnessed.

With such ideas in my mind, I observed that in the course of the 1970s the public image of the Nazi regime began to drift away from Jackson's fundamental accusation. Whereas I remember that the war had been at the core of our image of the Nazi past and in discussions with people from the older generation, now, in the late 1970s, war was gradually credited as a gentlemen's affair, and the only reproach was against war criminals who did not respect the gentlemen's agreements. It is appropriate to remind ourselves here that during the Second World War, the international law on war under certain circumstances allowed for, for example, the killing of civilian hostages in reprisal for "illegal" partisan activity. But at least one thing had always been clear: no law or treaty ever contemplated the industrialised mass-murder of civilians out of sheer racial hatred.

"Since the 1960s, most media, professions, and institutions involved in the representation of history developed routines for depicting Nazism - for instance, the routine of television dramas, of historical research and writing, or of political speechwriting and political ritual."21 Through these representations, the racial genocide perpetrated against the Jews of Europe ended up monopolising the historical image of the Nazi regime. The reception of Marvin Chomsky's TV serial Holocaust, which aired on German television in 1979, catalysed this shift. It was part of a "change in the social and media elaboration of history in general, and the Third Reich's genocide in particular", where "fictional narrations of history cover up the historians' discourse, imposing not only their iconography, but also their terminology". In this context, the serial "left perhaps, for the first time, a deep, enduring impression on the minds of the generation of the perpetrators' sons and daughters".22

I participated in the viewing with great satisfaction when I saw that so many people finally had turned their attention to a "forgotten" aspect of German history. ${ }^{23}$ On the other hand there was simultaneously a twofold repression behind the success of the miniseries in Germany, one which I grasped immediately, another which I understood only years later. The latter is that the (then) 
younger Germans' extreme identification with the victims ${ }^{24}$ functioned as a "quasi-religious eschatological promise for a redemption from guilt"; 25 it made of the German an exemplary model of collective memory centred around crime perpetration instead victimhood, which of course has many positive aspects ${ }^{26}$ but also some problematic sides, which I would summarise here as a removal of the evil into an elsewhere-past that tends to belittle our present. The repression I grasped immediately was that, in the new representation of the Nazi past, what Jackson's principal accusation had been in Nuremberg now played, if any, only a residual role. This happened at a time when the Helsinki process of détente suffered a serious setback. So, I saw the shift in the representation of "German guilt" also as a sign that the post-1945 taboo of war was to be overcome. Unfortunately I cannot say that subsequent years contradicted my fears.

\section{Before, behind, and after, the Wall}

It may be time now to wonder whether his juvenile experiences had any influence on the subsequent professional choices of this researcher. It is probably not difficult to understand why a young man with similar attitudes opted for university studies in political science, sociology and history. When, in the early 1980s, my postgraduate studies brought me to live in another country, active political militancy ended both for practical reasons and political prostration. It proved increasingly difficult to develop explanatory or self-deception strategies that could pretend to somehow excuse the stabilisation efforts of the repressive regime on the eastern side of the Wall. The political discontent which manifested itself in the 1980 protest movement in Poland and later spilled over to other countries, as well as the increasingly cynical and corrupt power structures which became apparent through the fog of political proclamations, demonstrated that the consent basis for a socialist alternative in this part of the world had been exhausted. At the same time, western society entered a period of consumerism and social disengagement. Since I ruled myself out of promoting political projects that were contrary to the manifest will of the overwhelming majority, I decided to better concentrate on my studies.

Were the cause-effect relations between studies and life experience all too straightforward, I should have become a scholar of German contemporary history. For a number of contingent motives and scholarly interests, which need not detain us now, in my PhD and later studies I looked instead mainly at Italian economic history. The main line of investigation was for several years the long-term continuities in the process of Italian industrialisation between the 1930s and 1960s. Most of the economic history studies of the time adopted a canonical separation between the fascist and the republican periods, implicitly or explicitly postulating an irreconcilable diversity in the economic policies and developments before and after 1945. If anything, it was my interest in layers of continuity between dictatorial and democratic regimes in Europe which linked my approach back to former reflections. Postulating a radical breach even against documentary evidence seemed to me another case of repression, for the sake of the present and its celebrated "miraculous" economic foundations. Corroborating similar myths against documentary and statistical ${ }^{27}$ evidence was, in my view, not something scientific historical enquiry should accept. 
Considering the political context of the 1980s, it will be easy to understand why the "historical optimism" that I had nurtured with already declining conviction during the years of political militancy had completely vanished. Teleological thinking, of which "historical optimism" is a derivative, was a theoretical problem which I had to tackle also as a professional historian. So, I did not wait until 1989 to throw it overboard because of a delusion with the failure of Marxism, the utopian project which I had already buried years earlier. Dismissing teleology was rather the fruit of a theoretical reflection which comprised the reception of developments in the physical sciences ${ }^{28}$ as well as of debates about historicity and causality that were inflaming the community of econometrists. ${ }^{29}$ In addition, the debates regarding the linguistic turn, as well as the philosophical and sociological discussions about systems, complexity, causality and change, reverberated in social and economic history. To put it bluntly, thermodynamics became to me a valuable metaphor for historical processes in general. I completely dismissed teleology as I became convinced that while the time arrow exists, it does not point in any predetermined direction, as it is produced by contingent events only. ${ }^{30}$

What I never renounced, however, was the need to critique the society I live in. As a matter of normative choice, I maintain that, like Sisyphus who rolls the rock uphill again and again, historians should feel the professional commitment to deconstruct the myths which society incessantly produces on behalf of its own past. ${ }^{31}$ If myths have an undeniable social function, demystification has too. That myths normally triumph over demystification is not proof of the contrary. While myths can rely on the settled truths of an existing power which recalls the history and memory of its own founding events, the practical consequences of critical deconstruction can rely only on the uncertain possibilities of future action. In a similar epistemological setting, I think that a "value free" appreciation of the past in a Weberian sense is much better for a critical understanding of the present and its possible future changes than a pathetic condemnation of the past according to present ideological standards. According to my experience with German public history and memory, the latter procedure tends to "otherise" what seems irreversibly gone, in favour of apologetic representations of the present. This is the sort of myth production from which, I think, the historian should abstain.

And there is another aspect of earlier experience that I would refer to as a founding element. I still feel committed to justice and the hope for a change in the way human society is designed and human beings relate to each other. The society I happen to live in is instead a society of increasing injustice. ${ }^{32}$ When I appeared on the scene of adult life, the European welfare-state model began its gradual decline down the road to "globalisation" and neoliberal economics.

After the Wall had fallen, the "end of history" was proclaimed. The rhetorical question mark in Francis Fukuyama's title hardly concealed the triumphalism behind the announcement of the "unabashed victory of economic and political liberalism". ${ }^{33}$ At that time I was already convinced that history has no end. More precisely, it would have an ending in time if it were understood as a merely human affair, but this does not mean that it has a purpose or a meaning which can be derived from that ending, or from the denying of that ending, which in eschatological terms is the same. And when there is no predetermined goal, it is also difficult to evaluate "progress" if not arbitrarily. Together with "modernity", this "progress" was another word which I began to use only in quotation marks. I take these words, as well as many others frequently used in the political rhetoric that surrounds me every day, as proof that western philosophy of history is still forceful. Where does 
the western certainty regarding the purpose of history come from? I think it stems from the conviction that there is always a meaning that transcends and explains the event; that it derives from a secularisation which transplanted eschatology into nonreligious contexts rather than expelling the sacred from political beliefs and social practices. I do not think that the purpose of history during the Sattelzeit became immanent, as Reinhart Koselleck argued, ${ }^{34}$ because the very concept of "humanity" to which his immanence refers is itself a transcendent one. The decisive philosophical question about history is not what meaning it has, but whether it has a meaning at all. Why did people raise such a "colossal question", as Karl Löwith labelled it? 35 The interest in similar problems now moved to the core of my renewed passion for the past.

In short, I became interested in the way western ideology is constructed and shapes the dominant representations of the world we live in by means of a political language that engulfs us every day. So, after 1989 I began exploring new fields and, since the start of this century, have almost abandoned research in economic and social history. According to the canon of disciplinary definitions, my new topics rather belonged to cultural and conceptual history. I was now especially interested in understanding how a philosophy of history managed to determine our mindset similarly to a religion, how it was able to shape the ideas of Europe and the nation, draw mental borders, establish hierarchies between people and territories, and make from geography a system of spatial metaphors. What interests me is also why, since the French Revolution, stimulating emotions became the kernel of political communication and collective identification. It was the aftermath of 1989 that let me look closer at 1789 and develop a curiosity for the seventeenth and eighteenth centuries in a way that I had never experienced before.

\section{Is personal experience helpful for writing about the past?}

This is my historical experience. I have never written so far about myself in an article and do not know whether my personal story means anything to anyone else. It is neither outstanding nor dramatic, neither heroic nor exemplary. So the only excuse I can advance for writing about it is that it was part of an experiment. Instead of tackling the relationship between biographical experience and history writing in abstract terms, I preferred here to show it at work in the case I am most familiar with. And since it was an experiment, it is now time for an assessment.

As a part of the experimental arrangement, I tried to recall not just events but also emotions of the past, which "crisscross the exuberant sphere of memory" and form the "existential background of the historian's work"; according to Antonella Tarpino, they can mediate between the historian's present and the collective imaginary of the past to which he wants to give voice. ${ }^{36}$ Whether this mediation was successful or not is, of course, up to the reader to decide. The reader's decision will probably also be influenced by personal impressions, which may be more or less in tune with the writer's emotions and the way he transmitted them. A reader of the writer's generation may remember similar situations, and identify himself or herself with some aspects of the writer's attitude towards life. Others may, on the contrary, reject the writer's narrated experience as they feel he misinterprets a period which they witnessed as well but think they understand it better. 
All I could then say in my defence is that I narrated my story sincerely as I remembered it. I did so in the most conventional of ways, through a traditional narration, which established causal nexuses between feelings and subsequent actions. For example: a wall is demolished; someone pops up to celebrate the end of history; I feel miffed at his triumph and so I start to reflect on "the end of history", studying texts and periods I earlier had paid little attention to. And so on. Within the limits of the methodological trust that we decide to invest in historical narration, we may deduce that the experiment successfully confirmed what Jaume Aurell postulates, namely "that our approaches inevitably are personal, governed by the particular contexts of our own histories, intellectual and academic training, politics, and social and professional commitments". ${ }^{37}$ So, we may conclude that my case delivers more proof for this (not so astonishing) result. It corroborates the usefulness of the recently successful "genre" of autobiographical writing by historians.

I could stop the assessment here, were it not for the limits hinted at above. How much can we trust the causalities which my memories have established? Does the degree of trustworthiness depend on the method? As far as the narrative method is concerned, Hayden White states "that historical writing, especially in a narrative mode, cannot be understood by bringing to it criteria of scientific consistency, logical consistency and so forth" ${ }^{38}$ The uncertain consistency of causality statements does not necessarily depend on the literary form of narration alone. When social scientists or economists use numerical time series to establish causalities with the help of statistical theories, they also produce a historical narrative notwithstanding the mathematical language. And even when their model does not include time variables, but others derived from "stylised facts", and the results are used to infer "real world" causalities, then still they rely on "some principle of storytelling". ${ }^{39}$ However mathematically perfect the operations are, the criteria for defining ceteris paribus conditions which reduce the "real world" complexities to make the model work have little to do with scientific consistency. So, the arbitrary and rhetoric character also of mathematically formalised narrations, as well as the importance of aesthetics regarding, for example, "the elegance" of a formal solution, are no less characteristics of these methods than of a literary narration. ${ }^{40}$

One might wonder also whether our foremost concern regarding the scientific character of history writing should be logical consistency. Similar axiomatic assumptions have a history as well and the world revolved also before someone stood up claiming that logical consistency was an "unquestionable a priori" to its correct understanding. My personal concern regarding the scientific status of historiography would rather be on reflectivity as a professional and mental habit. Self-reflection should be the contractual core business of all scientific communities. As a consequence, the literally narrating historian has no reason to feel inferior for a lack of "logical consistency", but the same historian has no excuse either for simply ignoring the causality problem. This problem cannot be put aside together with the long-established failure of post-Newtonian deterministic causality explanations when it comes to changes in complex environments.$^{41}$ Colloquial speech, literary writing, poetry and historiography normally contain plenty of cause-effect statements of different kinds and degrees. We can, for example, tighten or relent our "deterministic grip" on the correlation that one of our phrases establishes between two phenomena by employing the more peremptory verb form or the less peremptory noun form. Being "scientific" in my understanding means to be aware of similar aspects of our doing. We should consider what it means for doing history that literary narrations also construct causalities, and what it means that also in this type 
of narration "causal inference depends on more than just the data at hand; the validity of the conclusions always hinges on assumptions". 42

If this is correct, as I think it is, we should consider what the tacitly underlying assumptions of our own narration are. Concretely: what are the hidden, maybe unconscious, conditionings of my own story? Should I really believe in my story, as I in fact do? Can I pretend a reader would be persuaded by the causalities it establishes? This is not only a matter of language style, which can be more or less persuasive. It is also a matter of the materials the account is based on. As history writing is "a process of composition from the beginning; the selection of the materials, organising them, and writing about them are all phases of the compositional activity", ${ }^{43}$ the reliability of the composition depends also on what and how we select. A particularly awkward problem arises here when it comes to autobiographical accounts, as the material such accounts mainly rely on is memory. I would call it a source, for "material" might be associated with passive innocent matter. Sources are all but innocent, as all historians know when they approach them with professional circumspection. Among all sources, memory certainly deserves our greatest suspicion.

Memory is a present experiencing of past experience. If the principle source of a narrative composition is itself such a great storyteller, the source risks inadvertently determining how the story has to go. Unfortunately, memory is at the same time what we might call a inveterate liar, as it feigns detailed objectivity regarding emotionally loaded situations that the remembering person means to have lived through in the past. ${ }^{44}$ However, by reinventing the past it is only doing its job, because the reformatting of past experience for its smooth translation into present experience is exactly what we commonly call a well-working memory. If our memory stops composing credible tales that connect the present image of our self to its own past, the doctors may conclude that we are suffering from a personality disorder. In other words, memory is the central teleological organiser of the ever-changing, but always identically looking, "stories people tell to make sense of their own life". 45

As a historian I should not be satisfied with this observation when it comes to autobiographical narration, and much less when the narration is my own. Then I should render an account to the reader on the probability that the causal nexuses between my life experience and my professional choices, as well as the sense-of-justice constant and other alleged constants of my personality, are part of what Pierre Bourdieu called "the biographical illusion". ${ }^{4}$ It may be somewhat self-incriminating for us historians, but also a healthy antidote against ingenuities regarding the tales which make sense of our life, if with García Márquez we "always remember that the past is a lie, that memory has no return, that every spring gone by could never be recovered, and that the wildest and most tenacious love was an ephemeral truth in the end". ${ }^{47}$

The love of the past leads to another aspect of the autobiographical genre, that of emotions, which is seen as the inner, exclusive foundations of personal subjectivity. Cynthia Franklin notes that many academic protagonists of autobiographical writing try to escape from a "poststructuralist trap, one that delegitimates assertions of individual subjectivity or explorations of how individual experiences and intimate relationships are not completely institutionally determined. Rather than address these problems within theory through theory, some critics instead shift to the genre of 
memoir". Franklin situates the booming autobiographical accounts of "academic lives" within the wider context of a liberal and humanist revival in humanities since the late 1990s, and especially the post-September 11 era, stating that the formal properties of autobiography meet particularly well the basic ideological requirements of that revival. Many authors oppose liberalism and humanism in their academic works, but their autobiographical accounts often include "surreptitious or frankly nostalgic 'returns' to humanism". ${ }^{48}$

It is in this context that the personal dimension acquires a superior value because it is seen as the only aspect capable of establishing a credible experimental relationship to the past. Frank Ankersmit seems to suggest that experience should be freed from conventional academic constraints when he asks: "can the historian enter into a real, authentic, and 'experimental' relationship to the past - that is, into a relationship that is not contaminated by historiographical tradition, disciplinary presuppositions, and linguistic structures?" The way of establishing that relationship, he suggests, is through "subjective experience', that is the historian's own experience of the past". This is why the author supports "a rehabilitation of the romanticist's world of moods and feelings as constitutive of how we relate to the past. How we feel about the past is no less important than what we know about it - and probably even more so. ${ }^{\text {"49 }}$ Can this be interpreted as an appreciation of the cognitive and emotional enrichment that the autobiographical narration of the "historian's experience of the past" can yield? Or is it rather a point against historians' writing down their own experience? If experience is sublime and historiography incapable of grasping the sublime, then historians interested in communicating something about their own experience should perhaps better write a novel, paint a picture or compose a song, if they feel able to do so (and some historians do). Art is generally assumed to give better expression to the sublime.

Personally I am fine with alternative, for example artistic, ways of relating to the past within a larger framework of methodological pluralism. What I would find difficult to accept in a similar framework are claims of a superior degree of realism and authenticity of personal experience. Which past can sublime experience relate to in a more truthful, "as it was" manner that historiography cannot? Authenticity may be imagined, if at all, as a quality of a present act of remembrance and storytelling. It cannot be extended to the objects we remind ourselves of in the stories we tell. The assumption that the emotions which we associate with a certain situation are similar to the emotions with which we actually went through in that situation is unrealistic indeed. Perhaps this is of little importance to a concept of the sublime that already encompasses the incommensurability of experiences. But then the name of the real should not be called in vain. Methodologically circumspect historiography, at least, is aware of the unbridgeable hiatus between res gestae and historia rerum gestarum. It translates this awareness into an effort of objectification. Objectifying methods derive from the idea that objectivity is a chimera, and this seems more realistic to me.

Commonplace oppositions like those of body and soul, man and nature, passion and reason, and subject and object, to which the diagnosis of a "crisis in subjectivity" and the related proposals rely, deserve a critical examination when they are presented as unquestionable anthropological truths. We could conceive, on a system-theoretical level as well as on a neuroscience level, acting, creating, deciding and feeling as one and the same chaotic and path-dependent, self-organising process ${ }^{50}$ Under such concretely observable conditions, the individual human appears as an open 
system that massively interacts with its surroundings in any instant of his or her life; here the "l", as the absolute seat of subjectivity, looks more as an imagined than actually penetrable place, as George Herbert Mead pointed out. ${ }^{51}$ These are some possibilities of seeing things differently from what is the predominant view. The latter relies on the conceptual traditions of western methodological individualism, its concepts of reason and free will, and so on. It is a result of a philosophical development which originally built upon monotheist dogmas, and which sees the single human as the irreducible exclusive seat of subjectivity in history. So the irreducible subject became the abstraction of a presocial individual, whose innermost essence is called "the soul" in monotheist religions, "reason" by humanist and Enlightenment philosophy, "the unconscious" by psychoanalysis, and so on. According to psychoanalysis, in effect, the unconscious constitutes the "deep end of man's experience, anterior to any cognitive process".52

Similar views establish an interesting nexus between subjectivity and teleology, ${ }^{53}$ which unites biography and history in the parallelism of their purposes: the development of a mature human personality is the subject's individual telos, almost exactly as the stage of a mature and "true" humanity ${ }^{54}$ represents the species' telos. This is not a question of theological and philosophical speculation alone. These dogmas have been intertwined with social and power relations for more than two millennia. They were reinforced by secularisation around two centuries ago, a process which, among other things, gave rise to systematic pedagogical strategies. So the theological and philosophical message retroacts with the individual's views of him or herself on a day-to-day basis, both theoretically and practically. It is in this way that our biographical experience as westerners is well equipped with an all-encompassing sense of history and its purposes, which are insistently inculcated by education. It makes us measure our uniqueness under the light of an allegedly "higher" meaning of our life and the context in which it happens to take place. The same sense of history makes us incessantly seek transcendent meanings behind daily events. So it actually preshapes our life experience already before we gain it, and on the so-called psychological level it entraps our imagination in a tunnel vision of the past and future. It is, in a way, as Milena Jesenská once put it: "through experience the human being always impoverishes and never will be enriched"..$^{5}$ The problem of western experience is not only that it puts all beginnings under the spell of "the end", but also that it is unable to separate the meaning of cessation from that of purpose.

\section{The end}

Vita magistra historiae? If I had to conclude on the basis of the data exposed in the first part of this article and its elaboration in the second, I would dare to say that my experiencing history influenced my professional choices and my way of tackling the past as a historian. There is evidence in particular that my personal experience codetermined the selection of the subject matters I privilege and the way in which I conduct the research. But does this mean that life gave me a professional teaching? I would doubt that teaching is an appropriate term, at least if we think that it incorporates an underlying pretension of truth. 
In fact, I think that my demonstration would not be strong enough to make such a peremptory claim. That I made of my personal feelings an object of inquiry gave me no epistemological advantage. The often celebrated "subjective dimension" is not a truer or a more trustworthy dimension of history or life than any other. Personal experience is certainly a worthy subject of investigation and reflection, but as in the case of other subject matters we should be aware of the ambiguity of sources, tacitly underlying axioms and other conceptual conditionings - at least if we prefer a reflective way of talking about the past and appreciate independence from predominant narratives.

\section{NOTES}

1 It should however be noted that most academic memoires are based on "experiences that are not remarkable"; Cynthia G. Franklin, Academic lives: memoir, cultural theory, and the university today (Athens: University of Georgia Press, 2009), 4.

2 For an overview, see Jaume Aurell, "Making history by contextualizing oneself: autobiography as historiographical intervention," History and Theory 54/2 (2015): 244-268, here 244.

3 Franklin, Academic lives, 11.

4 Jesse Oris Farrow [Chester William Powers], "What about me," Lyrics Mode, http://www.lyricsmode. com/lyrics/q/quicksilver_messenger_service/what_about_me.html, accessed 3 Aug 2015.

5 Immanuel Kant, Critique of the power of judgment (1790), ed. Paul Guyer (Cambridge: Cambridge University Press, 2000), 90.

6 Hans Schneider, "Die Unerfüllte Zukunft: Apokalyptische Erwartungen im radikalen Pietismus um 1700," in Jahrhunderwenden: Endzeit und Zukunftsvorstellungen vom 15. Bis zum 20. Jahrhundert, ed. Manfred Jakubowski-Tiessen et al. (Göttingen: Vandenhoeck \& Ruprecht, 1999), 187-212, here 199.

$7 \quad$ "Rettet Angela vor dem Justizmord!" Der Spiegel, 8 Nov 1971, 128-146.

8 Tanjev Schultz, "Rubelscheine im Lehrerzimmer," Süddeutsche Zeitung, 28 Jan 2012, http://www. sueddeutsche.de/politik/jahre-nach-beschluss-des-radikalenerlasses-rubelscheine-im-lehrerzimmer-1.1269503, accessed 6 Aug 2015.

9 Manfred Histor, Willy Brandts vergessene Opfer: Geschichte und Statistik der politisch motivierten Berufsverbote in Westdeutschland 1971-1988 (Freiburg im Breisgau: Ahriman-Verlag, 1992), 110-112.

10 Peter Frisch, “Extremistenbeschluss: Zur Frage der Beschäftigung von Extremisten im öffentlichen Dienst (Leverkusen: Heggen, 1976), 95.

11 Carmen Everts, "Die Konzeption der streitbaren Demokratie," in Gegner und Grenzen der Freiheit: Herausforderungen für den demokratischen Verfassungsstaat, ed. Carmen Everts (Wiesbaden: Hessische Landeszentrale für politische Bildung, 2011), 49-73, here 67.

12 Dominik Rigoll, Staatsschutz in Westdeutschland (Göttingen: Wallstein, 2013).

13 Martin Kutscha, Verfassung und "streitbare Demokratie": Historische und rechtliche Aspekte der Berufsverbote im öffentlichen Dienst (Cologne: Pahl-Rugenstein, 1979), 69-84.

14 Histor, Willy Brandts vergessene Opfer, 29.

15 Rigoll, Staatsschutz, 16. 
16 Ibid., 308-327.

17 Arnold Zweig, Erziehung vor Verdun (1935) (Leipzig: Reclam, 1977), 229; the three colours of the Kaiserreich's flag were black, white and red.

18 Verhandlungen des Reichstags. XIII. Legislaturperiode. II. Session, vol. 306 (Berlin: Stenographische Berichte, 1916), 8-9.

19 Noam Chomsky, The imperial mentality and 9/11, 6 Sept 2011, http://www.tomdispatch.com/ blog/175436/tomgram\%3A_noam_chomsky\%2C_the_imperial_mentality_and_9_11/, accessed 6 Aug 2015.

20 Giovanni Amadori-Virgilj, Il sentimento imperialista. Studio psico-sociologico (Milan: Sandron, 1906), 71.

21 Wulf Kansteiner, In pursuit of German memory: history, television, and politics after Auschwitz (Athens: Ohio University Press, 2004), 5.

22 Marcus Stiglegger, Auschwitz-TV: Reflexionen des Holocaust in Fernsehserien (Wiesbaden: Springer, 2015), 37, 87.

23 Wilhelm van Kampen, Holocaust: Materialien zu dem amerikanischen Fernsehfilm über die Judenverfolgung im “Dritten Reich” (Wiesbaden: Landeszentrale für politische Bildung, 1982), 7-11.

24 Joachim Siedler, “Holocaust”: Die Fernsehserie in der deutschen Presse (Münster: LIT, 1984), 123.

25 Ulrike Jureit and Christian Schneider, Gefühlte Opfer: Illusionen der Vergangenheitsbewältigung (Stuttgart: Klett-Cotta, 2010), 11.

26 Highlighted by Paolo Jedlowski in the discussion "Memoria, nostalgia, utopia. Il potere politico dei sentimenti," ed. Elisabetta Tonizzi, Italia Contemporanea 263 (2011): 255-270, here 267.

27 For a late confirmation, see Emanuele Felice and Giovanni Vecchi, Italy's growth and decline, 1861-2011 (Rome: CEIS Research Paper Series 293/13, 2013), 16.

28 One for all: llya Prigogine, From being to becoming: time and complexity in the physical sciences (San Francisco: Freeman, 1980).

29 See, for example, Paul A. David, Path-dependence: putting the past into the future of economics (Stanford: Institute for Mathematical Studies in the Social Sciences, 1988).

30 Rolf Petri, "Pamphlet per il tempo storico," in Miti di fondazione e percezione del tempo nella cultura e nella politica del mondo contemporaneo, ed. Sergio Bertelli (Rome: Carocci, 1999), 37-68.

31 A similar view was expressed by Witold Kula, Riflessioni sulla storia (1958) (Venice: Marsilio, 1990), 27.

32 On the wealth level, for example, see Thomas Piketty, Le capital au21 e siècle (Paris: Editions du Seuil, 2013).

33 Francis Fukuyama, "The end of history?" The National Interest (Summer 1989): 3-18, here 3.

34 Reinhart Koselleck, Futures past: on the semantics of historical time (New York: Columbia University Press, 2004), 35-36.

35 Karl Löwith, Meaning in history (Chicago: University of Chicago Press, 1949), 4.

36 Antonella Tarpino, Sentimenti del passato (Florence: La Nuova Italia, 1997), 2-3.

37 Aurell, "Making history," 249.

38 Hayden White, "On the research and the writing phase of the historian's work," Historein 14/1 (2014): $71-74$, here 71. 
39 Deirdre N. McCloskey, How to be human (Ann Arbor: University of Michigan Press, 2000), 249.

40 See Donald N. McCloskey, The rhetoric of econometrics (Madison: University of Wisconsin Press, 1985).

41 Stephen Turner, “Cause, Teleology, and Method," in The Cambridge History of Science, vol. 7 (Cambridge: Cambridge University Press, 2003), 57-70.

42 Nick Barrowman, "Correlation, causation, and confusion," The New Atlantis (Summer/Fall 2014): 23-44, here 44.

43 White, "On the research," 73.

44 Daniela Palombo and Luciano Stegagno, “Emozioni e memoria: riscontri neuro e psicofisiologici," in Memoria e saperi. Percorsi transdisciplinari, eds Elena Agazzi and Vita Fortunati (Rome: Meltemi, 2007), 229-242, here 234.

45 Dan McAdams, "Personal narratives and the life story," in Handbook of personality: theory and research, eds Lawrence A. Pervin and Oliver John (New York: Guilford Press, 1999), 478-500, here 485.

46 Pierre Bourdieu, "L'illusion biographique," Actes de la recherche en sciences sociales 62-63 (1986): 6972.

47 Gabriel García Márquez, Cien años de soledad (Buenos Aires: Sudamericana, 1970), 339.

48 Franklin, Academic lives, 12, 3, see also 16-22.

49 Frank Ankersmit, Sublime historical experience (Stanford: University Press, 2005), 4, 10.

50 Tracy J. Mayne and James Ramsey, "The structure of emotion: a nonlinear dynamic systems approach," in Emotions: current issues and future directions, eds Tracy J. Mayne (New York: Guilford Press, 2001), $1-37$.

51 George H. Mead, Mind, self, and society (1934) (Chicago: University of Chicago Press 1974), 178; Idem, The philosophy of the present (1932) (New York: Prometheus, 2002), 91-96.

52 Flavio Manieri, "Psicoanalisi e antropologia nella genesi dello studio freudiano sulla cultura," in Sigmund Freud, Totem e tabù e altri saggi di antropologia (Rome: Newton \& Compton, 1997), 7-45, here 44; emphasis added.

53 Kant, Critique of the power of judgment, 302.

54 Johann Gottfried Herder, Ideen zur Philosophie der Geschichte der Menschheit (1784) (Berlin: Deutsche Bibliothek, 1914), 52. See also, for example, the parallels drawn between primitive Kulturstufen in the process of civilisation, and infancy, by Sigmund Freud, "Geleitwort," in John Gregory Bourke, Der Unrat in Sitte, Brauch, Glauben und Gewohnheitsrecht der Völker (Leipzig: Ethnologischer Verlag, 1913), iii-iv; and note the similarity of the role attributed to language, meaning and memory in two other seminal texts of western thought: Thomas Hobbes, Leviathan or the matter, forme, \& power of a common-wealth ecclesiasticall and civill (London: Andrew Crooke, 1651), 20, and Sigmund Freud, Das Ich und das Es (1923) (Leipzig: Internationaler Psychoanalytischer Verlag, 1925), 19-20.

55 Milena Jesenská, “Jugend," in Alles ist Leben: Feuilletons und Reportagen 1919-1939 (Frankfurt am Main: Verlag Neue Kritik, 1984), 70-73, here 71. 